\title{
eCOti
DiAno
}

Revista Mídia e Cotidiano

Artigo Seção Temática

Volume 13, Número 2, agosto de 2019

Submetido em: 17/06/2019

Aprovado em: 04/08/2019

\section{O feminismo como ator-rede nas transformações do processo da comunicação}

\section{Feminism as part of the actor-network theory in the process of communication transformation}

\author{
Márcia Eliane ROSA ${ }^{1}$ \\ Talita Bristotti Pereira da SILVA ${ }^{2}$
}

\section{Resumo}

Este artigo traz uma reflexão sobre as transformações no processo da comunicação que desconstrói a relação dialética de sujeito-objeto para a interação entre o sujeito, a tecnologia e a cultura e usa como objeto referencial o ativismo feminista no espaço digital. A análise, que tem caráter interdisciplinar, flertando nos campos da comunicação e tecnologia, é realizada a partir da ideia da ecosofia, conceito tratado pelo sociólogo francês Michel Maffesoli, e suas implicações no contexto contemporâneo. O pesquisador e sociólogo Bruno Latour e a ideia da Teoria Ator-Rede (TAR) conduz o olhar para as questões da produção de um significado híbrido de interação, que é produzida em rede dentro de um formato técnico e humano e na qual o próprio homem é parte central do processo.

Palavras-chave: Ecosofia; ativismo feminista redes digitais.

\begin{abstract}
This article reflects on how the communication process has changed, on how this deconstructs the dialectical relationship between subject and object and on the implications of this for the interactions between subject, technology, and culture. It then applies such reflections to feminist activism in digital spaces. The analysis has an interdisciplinary character, drawing from the fields of communication and technology. The research is guided by the perspective of ecosophy, a concept created by the french sociologist Michel Maffesoli, and by its implications for the contemporary context. The sociologist Bruno Latour, and his Actor-Network Theory (ANT), also guide this analysis

\footnotetext{
${ }^{1}$ Pós-doutora em Comunicação, é docente em regime de dedicação integral do PPG (Programa de PósGraduação) de mestrado interdisciplinar em Linguagens, Mídia e Arte da PUC-Campinas. E-mail: marciaer@terra.com.br

2 Mestre em Linguagens, Mídia e Arte pela PUC-Campinas e graduada em Comunicação Social Jornalismo pela mesma universidade. E-mail: talitabristotti@gmail.com
} 


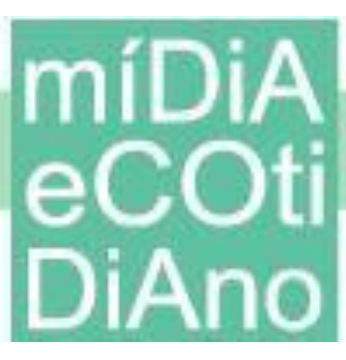

of issues of production of hybrid meanings of interaction, situated within a network, adopting a technical and human format in which men becomes a central part of the process.

Keywords: Ecosophy; feminist activism; digital networks.

\section{Introdução}

"Invaginação do sentido. Não é isso que caracteriza, no melhor dos casos, o espírito do tempo?" (MAFFESOLI, 2010, p. 59). Com esta pergunta, o sociólogo Michel Maffesoli provoca o pensamento sobre o processo da sociedade atual e suscita sobre a mudança de paradigma responsável por transformações de comportamento num contexto de inversão. É possível dizer, numa correlação estabelecida neste artigo, que este "espírito do tempo" de Maffesoli se refere a ações colaborativas, construções não hierárquicas e sujeitos que se caracterizam como atores que participam de um fluxo e, assim, constituem o formato de relações da atualidade que se estabelecem como redes.

Bruno Latour (2012) chama de Teoria Ator-Rede um híbrido de agentes que podem ser mediadores de ações. Nesse sentido, a proposta da teoria é que se estude e entenda os diversos pontos actantes que compõem as redes e assim analisar os rastros deixados por eles para que se possa ter uma compreensão das associações na sociedade. Di Felice (2012 e 2013) usa da teoria de Latour para entender as ações de ativismo nas redes digitais, através daquilo que irá denominar de net-ativismo. Neste conceito, entende que o ativismo digital é composto por diversos elementos actantes, de forma humana e tecnológica, ao mesmo tempo que flerta com os princípios da ecosofia.

A partir deste cenário, este artigo pretende trazer as reflexões destas transformações no universo da comunicação com o foco no estudo do ativismo feminista e seu movimento nas redes digitais como forma de análise da relação híbrida entre sujeito, tecnologia, cultura e o processo colaborativo. Para este estudo introdutório, de caráter quantitativo, foram observados os temas feministas que se destacam nas redes digitais desde 2004, quando o tópico feminismo começa a ter destaque, até março de 2018.

A primeira parte deste texto apresenta característica da sociedade contemporânea desviada do antropocentrismo, imbricada em conceitos da ecosofia e ensaiando o diálogo com o formato de ação utilizado nas redes. Num segundo momento, 


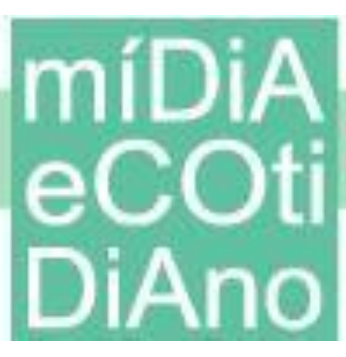

é apresentada a relação rede, ator e ativismo. Como reflexão, o texto é finalizado com o resultado da observação do feminismo como ator-rede.

\section{Paradigma contemporâneo: o sujeito e a natureza}

Perceber a descentralização do sujeito parece ser um elemento essencial para compreender o comportamento contemporâneo. Stuart Hall (2003) já considerou este processo ao mapear o nascimento e morte do sujeito moderno rumo à compreensão da fluidez identitária na pós-modernidade. Hall faz um mapeamento desde o renascentismo do século 16 até o denominado pós-moderno da contemporaneidade, trabalhando três momentos do sujeito: o do iluminismo, o sociológico e o pós-moderno. O autor parte de um "sujeito do Iluminismo" do século 18, que representava um indivíduo centrado, dotado de razão, consciência e ação. "O centro essencial do eu era a identidade de uma pessoa" (HALL, 2003, p.11). Esse indivíduo sofre uma primeira contribuição rumo à descentralização quando o filósofo francês René Descartes (1596-1650) estabeleceu o dualismo entre a "mente" e a "matéria", conhecido como o "sujeito cartesiano" que é racional, pensante e consciente. "Mas à medida que as sociedades modernas se tornavam mais complexas, elas adquiriam uma forma mais coletiva e social” (HALL, 2003, p.29). Diante desse novo quadro, o "sujeito moderno" passou a ser mais social, ou seja, a participar mais das novas estruturas que se formavam. A dualidade se dava agora entre indivíduo e sociedade num movimento interativo entre interior e exterior. A partir da segunda metade do século 20, esse panorama se modifica com o surgimento do modernismo. "Encontramos, aqui, a figura do indivíduo isolado, exilado ou alienado, colocado contra o pano-de-fundo da multidão ou da metrópole anônima e impessoal" (HALL, 2003, p.32). Para o autor, a leitura que se pode fazer desse momento é que o indivíduo do modernismo se fragmenta e, mais ainda, desloca-se daquele "sujeito cartesiano", através de diversos eventos da atualidade daquele período, a qual Hall chama de descentração.

Para que aconteça essa transferência total para o "sujeito pós-moderno", o autor cita um processo com cinco descolamentos. O primeiro se faz sob a interpretação 


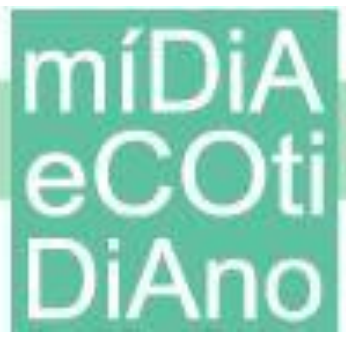

de Karl Marx (18818-1883) sobre alguns autores que apontam a existência de uma essência universal de homem e que é característico de cada indivíduo singular. Um segundo descentramento vem da descoberta do inconsciente por Freud, mas sob o olhar de Lacan que observa uma origem contraditória da "identidade". Assim, partimos do pressuposto que a identidade é realmente formada ao longo do tempo, através de processos inconscientes, e não um elemento inato, existente na consciência no momento do nascimento. Existe sempre algo "imaginário" ou fantasiado sobre a unidade (HALL, 2003, p.38). Hall caracteriza como o terceiro descentramento as mudanças que partiram de Ferdinand Saussure, com a análise do trabalho linguista-estrutural, quando se percebe que a língua não é um sistema individual e sim social. O quarto deslocamento do indivíduo aparece com o filósofo francês Michel Foucault, com o estudo do homem moderno e a importância do "poder disciplinar" das práticas da vida. O autor cita, por fim, o impacto do feminismo como motivo do quinto descentramento. Importante ressaltar que quando Hall circunda ao universo do feminismo faz relação direta às características dos "novos movimentos sociais" e com a descentração do sujeito cartesiano e sociológico.

Alguns outros teóricos salientam sobre a importância de lançar o olhar para a questão de que existe uma descentralização do homem no controle de si mesmo e ao mundo ao seu redor, desconstruindo a imagem do "Homem Vitruviano", representado no século 16 diante das certezas de um universo racional onde o homem idealiza o controle sobre a natureza. Neste universo e na razão, o homem busca o eterno perfeito (MORE, 1992). Esta sobrevalorização da razão foi tomada por Friedrich Nietzsche (1844-1900) quase que como um presságio de declínio, de falta de vitalidade experimentada a partir do período pós-socrático. Para o filósofo, o racionalismo ocidental atrofiou a vida humana no uso de sua potência. O uso da ciência a favor da humanidade poderia ser indiscutível, mas, "todavia, as ciências não foram capazes de criar um novo nexo entre a teoria e a práxis da vida" (JULIÃO, 2008, p.158). É o que trouxe ao debate Nietzsche. Maffesoli (2010) também questiona o "mito do progresso" a partir do racionalismo e do antropocentrismo e alerta para a inversão desse processo apontando para uma mudança de paradigma e a busca pela natureza onde existe uma aceitação daquilo que é e explica: 
A natureza trágica não é mais negação, do pecado, do mal, da imperfeição. Em suma, ela não é mais a negação de todos esses ingredientes que fazem parte de nós. Mas, sim, aceitação do claroescuro da existência. A natureza, compreendida dessa maneira, substitui a perfeição pela completude (MAFFESOLI, 2010, p. 63).

Utilizando-se do termo "invaginação do sentido", Maffesoli se refere a um retorno essencial das coisas como uma forma de recuperar o homem em seu estado natural e não ideal. A partir daí o homem recupera o processo orgânico e neste cenário o progresso é sinônimo do restabelecimento de uma coisa ou de uma pessoa em seu estado natural com seus fluxos e fluidos originários. Para ele, é o fim da era "espermática", passiva, à espera de um herói que fecunda. É a saturação das características "progressistas". Este retorno não se trata de um regressar, mas aceitar o que é, o que chama de ingressão, "Ingresso versus Progresso" (MAFFESOLI, 2010, p. 83). Neste contexto, o homem deixa de olhar para fora, de uma forma idealizada, buscando a perfeição e passa olhar para dentro de sua própria natureza para solucionar as questões.

A natureza e a ciências humanas já eram temas de pesquisa para Johann Wolfgang von Goethe (1749-1832), no século 19, quando se interessou pelos caminhos da biologia para propor este diálogo com Carl Friedrich Philipp von Martius (1794-1868), o botânico alemão que realizou uma expedição na flora brasileira nos anos de 1817 a 1820. Os resultados deste trabalho passaram pelos estudos de Goethe, que, naquele período, discorria com o botânico para avançar na ideia sobre a tendência-espiral ativa na vegetação. Segundo suas reflexões, o reino vegetal é determinado por dois sistemas (vertical e espiral) que atuam de forma conjunta. O sistema vertical teria aspectos com o "princípio de apoio masculino" (MAINBERGER, 2010) que conduz o desenvolvimento da planta como produtor a partir de seu germe, fortalecendo fibras e mantendo de forma permanente. O espiral, um sistema que alimenta, trata daquilo que está em aperfeiçoamento e de forma efêmera. É possível pensar, neste caso, em um elemento com aspectos femininos.

Esta leitura da biologia também é ponto de apoio para o pensamento de Maffesoli que se utiliza das reflexões sobre o masculino e feminino na observação das transformações contemporâneas e também dialoga com Goethe: 
Espiralidade, segundo Goethe, é a característica do mundo vegetal. Espiral que representa o elemento feminino que se opõe à verticalidade masculina. Verticalidade que se pôde mostrar que era o símbolo da dominação sobre a natureza. É contra esta que se opõe a espiralidade que segue os meandros das eflorescências naturais ou o labirinto do vivido. Espiral cuja forma artística seria o barroco em que os diversos elementos interpenetram-se e estão ligados organicamente. (MAFFESOLI, 2010, p. 100)

Assim, o "espírito do tempo", para Maffesoli, teria a "sensibilidade ecológica", dentro de uma forma de pensar que chama de ecosofia. Neste paradigma, a bússola também é orientada por sentidos e um pensamento orgânico. "O pensamento mecânico raciocina, o orgânico ressoa" (MAFFESOLI, 2010, p. 98). A proposta é, portanto, estabelecer na prática os elementos encontrados no processo orgânico da natureza. "São práticas da vida corrente, mais vividas do que pensadas" (MAFFESOLI, 2010, p. 102). A natureza e seus elementos são o que determinam a potência e a força do movimento, como uma forma de referência que mudará as ações em um viver de forma natural.

Talvez seja esse conhecimento que renasce como uma espécie de ecosofia que ainda não sabe como nomear-se. Que não consegue, seguramente, teorizar-se, mas que, na vida cotidiana, vive-se na moradia, na alimentação, na vestimenta. Nesses diversos elementos que formam a verdadeira cultura, não são mais a separação e o corte que prevalecem, não é mais a razão universal que vai servir como padrão. Muito pelo contrário, o que subjetivamente se capilariza nas práticas cotidianas é a preocupação com a conjunção. $\mathrm{O}$ corpo e o espírito intimamente mesclados. (MAFFESOLI, 2010, p. 101).

Com a ideia da ecosofia, Maffesoli aponta para importantes mudanças de comportamentos contemporâneos que parecem justificar as novas relações no universo da comunicação e também nas redes digitais. Não se trata mais de situações dicotômicas ou de um formato determinado por hierarquias. Tratamos do orgânico onde o colaborativo (emissor e receptor) está presente no mesmo ator. O processo é determinado pelas pessoas, fluxos e cultura. 
Desde que o homem aprendeu a se relacionar com a tecnologia, estabelece-se como referência a relação dicotômica diante do processo tecnológico que o impingia numa relação de hierarquia e de necessidade de dominação em relação à técnica. Estabeleceu-se como forma padrão a relação sujeito-objeto no formato linear e dialético, ou seja: A (emissor) se relaciona com B (receptor) de forma direta e com retorno (feedback) automatizado desta comunicação. Este é o chamado modelo clássico da comunicação numa referência à Teoria da Informação, de Shanon e Weaver (1949).

No entanto, este conhecido modelo comunicacional dos monopólios nos formatos de rádio, jornal e TV sofreram transformações ao conhecer e interagir com o processo de comunicação que foi determinado pelo formato das novas mídias ligadas no modelo de redes. As redes digitais instauraram uma troca de fluxos que já não era linear de A para B, mas de todos para todos, com retornos diversos e sem determinação de quem é o emissor ou receptor neste processo. Este novo procedimento trouxe simultaneamente um novo formato para a comunicação e também uma nova forma de relacionamento entre as pessoas. A sociedade contemporânea percebeu um novo modelo comunicacional e cultural onde o homem está inserido como parte do próprio processo de comunicação.

Analisar a natureza das transformações da ação na época contemporânea significa, portanto, não somente analisar as novas práticas de interações em redes, mas, sobretudo, investigar os novos significados emergentes do social e da participação no interior dos novos contextos simbiótico-transorgânicos. Nesses, o humano e o tecnológico desenvolvem novas formas de interações que, superando a forma antropocêntrica, apontam para práticas tecnológicas da sociabilidade onde as práticas sociais tradicionais são flanqueadas pelas interfaces digitais e pelas formas de interações entre humanos e tecnologias da informação, constituídas por fluxos comunicativos em rede que parecem anular a distinção analógica entre emissor e receptor (DI FELICE, 2012, p. 41).

A ecosofia está presente em todos os setores da sociedade como uma mudança de paradigma que muda comportamentos e traz processos colaborativos, com menos hierarquias, gera comportamentos menos passivos de forma mais fluida e não controladora. Substitui a perfeição (racionalizar) pela completude. No entanto, a proposta 


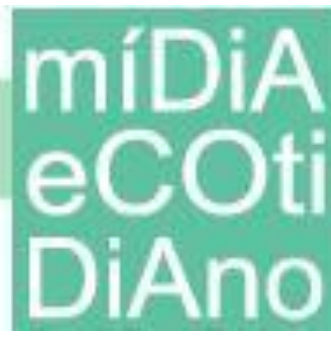

de inversão e da ecosofia também propõe dificuldades na ação, visto que é comum a busca por seguranças e certezas no cotidiano.

\section{A rede como ator de ações ativistas}

Os estudos do sociólogo francês Bruno Latour têm mostrado um pensamento muito semelhante ao de Michel Maffesoli, apesar dos teóricos não utilizarem os mesmos termos. Assim como Maffesoli, Latour também critica o processo pouco orgânico pelo qual passamos intensamente no último século e enfatiza a separação do que chamou de "coisas-em-si" e os "humanos-entre-eles" no processo em que o homem dominou os demais elementos, propondo, então, uma "nova forma que se conecta ao mesmo tempo à natureza das coisas e ao contexto social, sem, contudo, reduzir-se nem a uma coisa nem a outra" (LATOUR, 2013, p. 11). O autor defende que nunca fomos modernos, pois a modernidade e o racionalismo, na verdade, falharam em separar os humanos dos nãohumanos. Durante o período moderno, na visão do sociólogo, o que aconteceu foi uma amplificação das relações entre os elementos da sociedade, mesmo apesar de operarem em um sistema que separou, pelo menos em tese, a divindade, o humano e o natural. Para Latour (2013, p. 47), a modernidade falhou por não entender a "correspondência direta entre a ordem social e a ordem natural" e por não permitir que esses desdobramentos fossem pensados. Assim, a proposta do autor é que a construção do conhecimento seja feita em redes híbridas, que levam em consideração a subjetivação do homem, natureza, tecnologia e cultura. Afinal, "tudo acontece no meio, tudo transita entre as duas, tudo ocorre por mediação, por tradução e por redes" (LATOUR, 2013, p. 43).

Outro aspecto importante do pensamento de Latour (2012) é a tentativa de mudar o entendimento da palavra "social". Ele argumenta que as mudanças provocadas por essa outra recepção nas relações entre humano, cultura e tecnologia fizeram com que o social fosse diluído. Na sociedade moderna, na qual a ciência era uma "necessidade absoluta", convencionou-se usar o social para denominar o campo do humano, distinguindo-o e separando-o de outras esferas como da psicologia, economia ou direito. Era o social para explicar o que nós, humanos, fazemos em sociedade. Para o autor, 


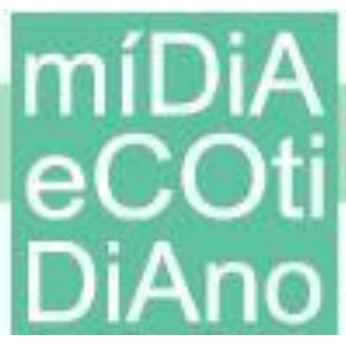

porém, a palavra "social" deve ser entendida para explicar algo heterogêneo, que representa uma série de associações entre elementos diversos. "Sob este ângulo, o adjetivo 'social' não designa uma coisa entre outras, como um carneiro negro entre carneiros brancos, e sim um tipo de conexão entre coisas que não são, em si mesmas, sociais" (LATOUR, 2012, p. 23). É entender que todos os elementos heterogêneos precisam ser reunidos novamente, em um contexto híbrido. O social, nessa visão, só é possível de se enxergar pelos traços que dissemina quando "uma nova associação se constitui com elementos de modo algum 'sociais' por natureza” (ibidem, p. 27).

É dentro deste contexto de pensamento, do que chamou de "sociologia das associações", que Bruno Latour vai propor a Teoria Ator-Rede (TAR) para poder entender esses outros agentes "não-humanos" que desempenham papéis na sociedade, entendida aqui como uma rede de lugares. Essa visão quer entender a sociedade e a comunicação como algo híbrido, subjetivada por uma multiplicidade de agentes, que ele denomina de actantes, e não apenas pelo homem, que até então era visto como aquele que cria e define o mundo.

Lemos e Pastor (2014, p. 1018) resumem o pensamento de Latour: "o social é associação, toda ação é mediação, e os agentes são actantes ou intermediários. Não há essência e há simetria entre humanos e não-humanos". A leitura que os autores fazem sobre a teoria de Latour (2012) é que o intermediário seria aquele que passará a informação sem modificar a ação, enquanto o actante deve ser entendido como aquele que adotará uma ação que trará um resultando, deixando rastros. Para Latour, segundo os autores, são esses rastros das ações em rede que devem ser o objeto de análise. "O princípio fundamental é que as redes constituem a vida social, não como estrutura que a enquadra, mas como relação que a inaugura" (LEMOS, PASTOR, 2014, p. 1018). Assim, a proposta do sociólogo é entender os pontos que formam essas redes híbridas, onde qualquer elemento pode e deve ser visto como um ator-rede. Nesse sentido, a Teoria AtorRede pode dialogar com a ecosofia no sentido em que possibilita um outro olhar para estas associações, que acontecem em um espaço fluido e de colaboração entre o homem, cultura, natureza e tecnologia.

Dentro deste contexto de mudanças das práticas sociais e comunicacionais e das associações colaborativas, pode-se afirmar que a sociedade em rede também altera o 


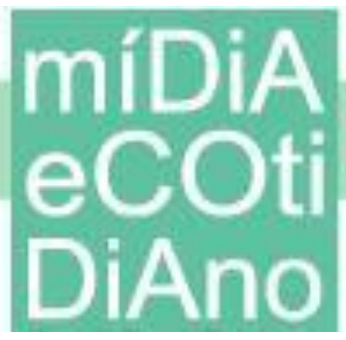

desenvolvimento da interação política. Usando a Internet como ferramenta de organização e de comunicação, os movimentos sociais contemporâneos são formatados em dinâmicas coletivas e, de acordo com Di Felice (2013b), são o resultado da "interação fértil entre o humano e a técnica" (2013b, p. 273). O autor se vale do termo net-ativismo, simplificação da expressão Network-Ativismo, para entender esse ativismo surgido em e nas redes, que se configura como o resultado entre a interação de sujeitos e tecnologias de informação. Ao ampliar o conceito estudado por Edward Schwartz, que estava voltado para uma democracia eletrônica e participação política, Di Felice $(2012$; 2013) ressalta que esse ativismo contemporâneo, que se articula no espaço digital, é formado por uma identidade global colaborativa.

$\mathrm{O}$ autor sugere que os movimentos que surgem nas redes digitais e sem um espaço geográfico delimitado vão de encontro às tradições políticas europeia-ocidental por serem prioritariamente anônimos, ou seja, sem uma organização hierárquica definida, por recusar tomar o poder e por preferir o desaparecimento. Esse tipo de ativismo "resultam da sinergia de atores de diversas naturezas, pessoas, circuitos informativos, dispositivos, redes sociais digitais, territorialidades informativas" (DI FELICE, 2013b, p. 276). Além disso, esses movimentos têm outras características como a luta com objetivos múltiplos, serem imprevisíveis e recusarem a institucionalização.

Para Di Felice (2013a), a Teoria do Ator-Rede pode ser identificada de dois modos no net-ativismo. Uma delas é pela rede disseminativa, na qual o autor entende como a estrutura de organização das ações dos movimentos, onde é possível evitar o questionamento da autoria dessa ação, limitando a análise às questões políticas e dialéticas entre esse coletivo de agentes e o Estado. A segunda forma é descrita como uma rede de diálogo e pode ser identificada como um espaço "que constroem suas ações através da constituição de uma complexa ecologia que reúnem e agregam humanos, circuitos informativos, interfaces, dispositivos de conexões, banco de dados, social network, imprensa, mídias, etc.” (2013a, p. 64). Ou seja, a rede pode ser tanto um espaço para organização da ação, como também um agregador dos actantes que participam das ações.

Para Di Felice (2012), mais do que analisar as novas práticas de interações sociais, no net-ativismo é preciso entender os significados das formas de interações entre o humano e o tecnológico. Isso porque o autor entende que as práticas tecnológicas são 


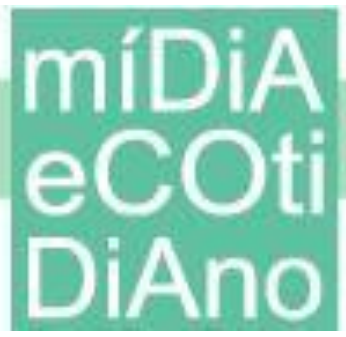

formadas por "fluxos comunicativos" em rede que caminham no sentido de anular a relação analógica antes construída entre emissor e receptor. A construção coletiva do saber é uma visão que vai de encontro com a forma analógica da comunicação, na qual a mensagem era emitida ao receptor por apenas um canal. Nessa versão tradicional, a mídia se limitava a distribuir a lógica de consumo e dos valores da sociedade capitalista. Com a Internet, os fluxos informativos tornam-se colaborativos e as interfaces permitem velocidade na troca de informação "de todos para todos".

Di Felice (2013a, p. 58-59) ainda afirma que para entender os movimentos net-ativistas é preciso ter em mente que passamos de uma mídia alternativa, marcada pela produção de conteúdo contracultural, para a mídia participativa, que articula o diálogo a partir do compartilhamento de conteúdo. $\mathrm{O}$ ativismo que tem origem nas redes digitais é marcado pelo fluxo informativo e conexões sincrônicas, bem como pela valorização do anonimato e recusa da institucionalização. Aliadas à Internet, percebe-se que essa outra forma de fazer ativismo é gerada por este contexto de organização social em rede, entendida aqui como o paradigma da ecosofia, em que os diversos atores do processo constroem coletivamente a ação.

\section{Feminismo como ator-rede}

O feminismo e o feminino erguem-se como elementos de referência nas transformações contemporâneas. Neste texto, Hall (2003) trouxe a questão do feminismo como importante dado no impacto e mudança na descentralização do sujeito social. Já o feminino é base de analogia para os pensamentos de comportamento de Goethe e Maffesoli (2010) ao tratar a ciência em diálogo com a biologia e a filosofia. Quando se observa as redes digitais, o movimento feminista parece ter encontrado um ambiente para discutir pautas e construir saberes coletivos, dentro de um contexto em que a forma de comunicação deixa de ser unidirecional e a informação passa a ser constituída por diversos agentes. Gleidiande de S. Ferreira (2013), ao analisar o movimento Marcha das Vadias $^{3}$ no Brasil, argumenta que a Internet vem se apresentando como uma importante

\footnotetext{
3 A Marcha das Vadias surgiu em 2011 no Canadá, mas atualmente é um movimento mundial, e pode ser "identificada como uma reação à naturalização das violências contra as mulheres" (FERREIRA, 2013, p. $34)$.
} 
ferramenta do feminismo no País por divulgar o feminismo e abrir espaço para o debate entre setores da sociedade, o que, na visão da autora, não era possível dentro do formato tradicional da mídia. Esse espaço de diálogo nas redes digitais ainda tive um outro efeito, que foi o de incitar debates sobre o movimento nas rádios, televisão e jornais.

Desse modo, a internet se constrói como um espaço de publicação feminista alternativa que, diferentemente dos panfletos e fanzines que fizeram parte da mobilização das feministas até meados dos anos 90, possibilita uma maior difusão dos materiais produzidos e também de um retorno por parte das pessoas que tem acesso à essas publicações. Ou seja, a internet se apresenta como um lugar em que as ideias podem ser divulgadas e debatidas. (FERREIRA, 2013, p. 35).

Apesar de o movimento feminista ter iniciado sua luta ainda no século XIX, tem-se a percepção, pelo menos no Brasil, de uma crescente exposição midiática sobre o tema feminismo nas redes sociais digitais a partir de 2015. A ferramenta Google Trends, que levanta o histórico de busca por termos no Google, é um indício dessa maior exposição do movimento feminista na mídia brasileira. De acordo com o gráfico disponibilizado pela ferramenta, que inicia a contagem de buscas por termo a partir de 2004, a palavra "Feminismo" dentro da categoria de ideologia política começa a ganhar destaque no Brasil a partir de outubro de 2015, talvez pela inclusão de temáticas feministas no Enem (Exame Nacional do Ensino Médio) daquele ano, em uma prova que foi prestada por 5,7 milhões de estudantes do Brasil ${ }^{4}$. No exame, uma das questões abordava um trecho do livro "O Segundo Sexo", da escritora francesa Simone de Beauvoir, enquanto a redação do Enem 2015 pedia a discussão sobre "A persistência da violência contra a mulher na sociedade brasileira". Este fato gerou uma grande discussão na sociedade brasileira, sendo tema de reportagens jornalísticas e debates nas redes sociais digitais, como o Facebook e o Twitter. Ainda pelo gráfico disponibilizado pela ferramenta, é possível ver que até abril de 2017, quando se buscava a incidência de

4 Informação obtida no site Portal Brasil, do governo federal. Disponível em: <http://www.brasil.gov.br/educacao/2016/01/resultado-do-enem-sera-divulgado-hoje>. Acesso em 24 abr. 2017. 


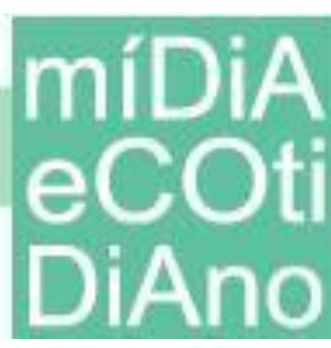

pesquisa pela palavra "feminismo" desde 2004, o maior pico de buscas da história se deu em março de 2017 no Brasil, conforme é possível ver a seguir:

\section{Figura 1 - Feminismo na ferramenta Google Trends}

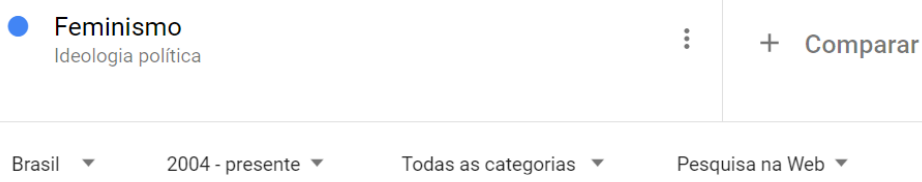

Interesse ao longo do tempo ?

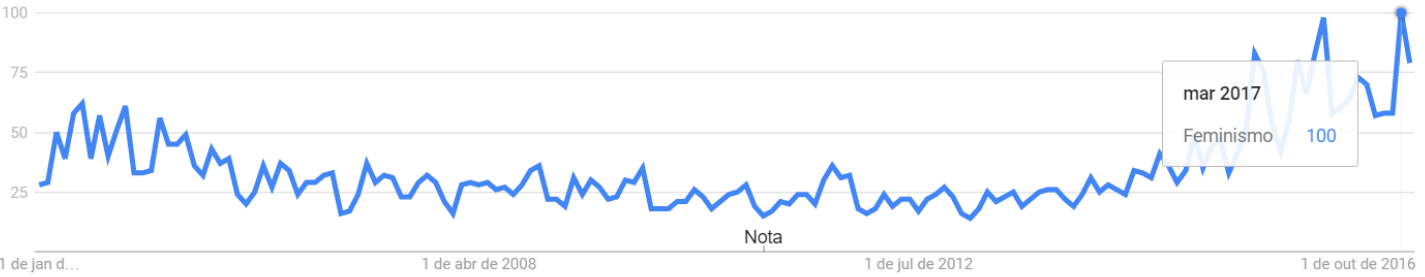

Fonte: Google Trends.

Talvez seja possível explicar esse pico nas buscas em março de 2017 pelo fato que, neste ano, o Dia Internacional da Mulher, comemorado em 8 de março, foi marcado por uma greve geral em pelo menos 48 países, inclusive no Brasil, em oposição ao feminicídio, o machismo, violência e desigualdade entre gêneros. $\mathrm{O}$ manifesto foi convocado por ativistas em um texto publicado no jornal britânico The Guardian ${ }^{5}$, sugerindo uma aliança global entre as mulheres. Nas redes digitais, o movimento 8M Brasil $^{6}$, que liderou o chamamento do protesto, criou uma página no Facebook, no

5 Manifesto publicado no jornal The Guardian: 〈http://bit.ly/30tz4gj>. Acesso em: 7 maio 2017.

$6 \mathrm{O}$ movimento $8 \mathrm{M}$ representou uma marcha mundial de mulheres contra a violência e pela igualdade de gêneros. O nome é uma abreviação para 8 de março, data em que é celebrado o Dia Internacional das Mulheres. 
Instagram e no Twitter para mobilizar o público, além de um website $e^{7}$ com textos e elementos gráficos explicando a proposta de greve geral.

Ainda por outro gráfico disponibilizado pela ferramenta, é possível ver que até março de 2019, quando se buscava a incidência de pesquisa pela palavra "feminismo" desde 2004, o maior pico de buscas da história se deu em setembro de 2018 no Brasil, conforme é possível ver a seguir:

Figura 2 - Interesse ao longo do tempo

Brasil -2004 - presente $>$ Todas as categorias $\rightarrow \quad$ Pesquisa na Web -

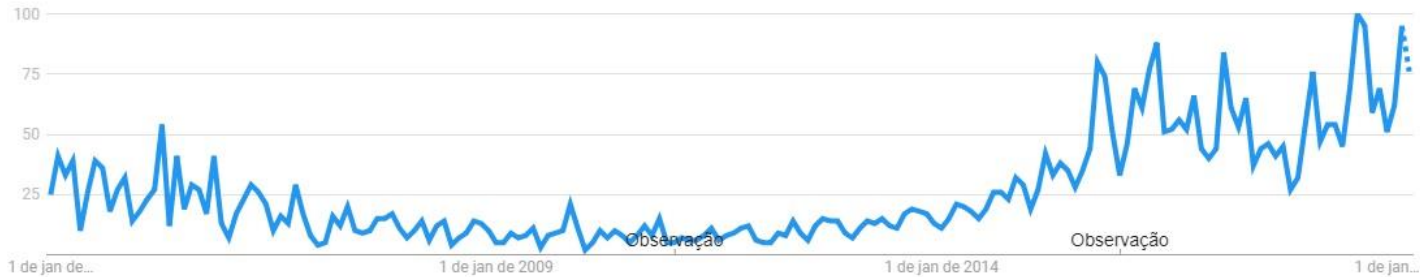

Fonte: Google Trends.

Neste outro gráfico, nas buscas em setembro de 2018, o pico pode ser explicado pelo fato de que, naquele ano, houve uma eleição presidencial marcada por polêmicas, inclusive no campo de discussão de gêneros. Nas redes, percebeu-se um movimento de mulheres contra um dos candidatos, Jair Bolsonaro, por meio de grupos no Facebook, que ficou conhecido como Mulheres Unidas Contra Bolsonaro. O propósito do movimento era chamar atenção para o modo como o então presidenciável se referia às mulheres, muitas vezes diminuindo o papel do sexo feminino dentro da sociedade, mobilizadas contra os "discursos de ódio, sexistas, homofóbicos e racistas" de Bolsonaro - em 3 dias, segundo reportagem do Huff Post Brasil, mais de 1 milhão de mulheres já tinham aderido ao grupo. Além das redes, o grupo organizou protestos em diversas cidades do Brasil.

$7 \mathrm{O}$ website do movimento 8M Brasil, que disponibiliza o link das redes sociais, é o: <https://www.8mbrasil.com/>. Acesso em: 12 abr. 2017. 
Ainda no contexto eleitoral, um outro movimento que surgiu de uma pauta feminista ficou conhecido como \#EleNão. O uso da hashtag nas redes sociais, principalmente no Facebook, Instagram e Twitter, se popularizou entre mulheres, anônimas ou famosas, e também entre homens que não concordavam com o discurso do então candidato. Uma semana antes do primeiro turno das eleições daquele ano, o movimento liderado por mulheres foi às ruas em 29 de setembro de 2018 em pelo menos 114 cidades brasileiras ${ }^{8}$ e mais de 50 países. A pauta do movimento era baseada nas falas machistas e misóginas que Jair Bolsonaro proferiu durante toda sua vida política, mas também abarcou outros contextos, como a luta pelos direitos humanos, contra o fascismo e o racismo, bem como uma pauta que ressaltava a importância das lutas pela igualdade.

Esses movimentos nas redes podem explicar o aumento nas buscas pelo feminismo, já que as mobilizações contra Jair Bolsonaro estavam ligadas, prioritariamente, aos grupos feministas. Assim como em muitas outras mobilizações organizadas na Internet, esse movimento não tinha uma liderança específica, apenas utiliza as redes como um espaço de disseminação e de diálogo (DI FELICE, 2013a), tinha objetivos múltiplos, não tiveram uma institucionalização e se articularam de modo muito semelhante ao que Di Felice (2012 e 2013) propõe como net-ativismo.

\section{Considerações finais}

Com este estudo, foi possível compreender que os espaços digitais deixaram de ser apenas uma ferramenta comunicacional ou de aproximação entre as participantes do feminismo no Brasil. Dentro da lógica de Bruno Latour (2012), as redes digitais e os dispositivos tecnológicos, que permitem acesso à Internet, passam a se constituir como actantes. Observa-se, neste aspecto, que a ecosofia e a Teoria Ator-Rede são fundamentais para tentar compreender esse novo ativismo digital. Na ecosofia, as relações entre o homem e os demais elementos que constituem a sociedade passam a ser entendidas de uma forma natural, não mais de dominação, enquanto a Teoria Ator-Rede possibilita pensar nesses elementos como produtores de uma ação. O conceito de net-ativismo,

8 Informações disponíveis em: <https://bbc.in/2ziWvgo>. Acesso em: 31 jul. 2019. 
portanto, agrega quando se precisa entender o ativismo digital contemporâneo como resultado dessas interações entre o homem, natureza e tecnologia.

A partir dos elementos apresentados neste artigo sobre o ativismo feminista nas redes digitais, não é possível traçar uma linha de conclusões. O propósito foi exemplificar um aspecto dentro deste objeto que permita observar ação de atores no universo das novas transformações da comunicação. É latente, portanto, perceber as interrelações propostas em um contexto onde a comunicação não mais se estabelece como um sistema dado e fechado, com suas funções hierárquicas e fecundadoras. Os atores participam como constituintes de uma rede de forma orgânica, proporcionando um fluxo que vai ser conduzido de forma aleatória e ativa, segundo a composição desta relação estabelecida. Nesta fluência, os agentes podem ser o sujeito, a tecnologia ou a cultura em sua forma identitária e social.

Perceber os deslocamentos do sujeito e um modo de viver não mais antropocêntrico faz expandir o olhar para os aspectos do retorno ao natural, que pode ser apresentado no movimento fluído das folhas, no processo fisiológico da constituição masculina e feminina - que fazem analogias ao modo passivo e ativo. Por tempos, a arquitetura da comunicação se estabeleceu no movimento de cima para baixo (up dow) e fecundou aquilo que aguardava seus comandos e novos caminhos. As inter-relações de rede criam uma nova concepção entre sujeito e natureza. Pensar o paradigma contemporâneo não é apenas contextualizar um espaço no qual os objetos do feminismo e da comunicação estão inseridos, mas compreender que todos estes elementos funcionam coexistindo e sendo parte central de um mesmo processo.

\section{Referências}

DI FELICE, M. Netativismo: novos aspectos da opinião pública em contextos digitais. In: Revista Famecos, v. 19, p. 27-45, 2012. Disponível em: 〈http://bit.ly/2Hmdumq>. Acesso em: 8 nov. 2016.

Ser redes: o formismo digital dos movimentos net-ativistas. In: Matrizes, v. 7, p. 49-71, 2013a. Disponível em: <http://bit.ly/2PaBYp3>. Acesso em: 8 nov.2016.

. Net-ativismo e ecologia da ação em contextos reticulares. In: Contemporânea

| Comunicação e Cultura, v.11, n.02, p. 267-283, mai-ago, 2013b. Disponível em: $<$ http://bit.ly/31Xaftf>. Acesso em: 30 mar. 2017. 
FERREIRA, G.S. Feminismo e redes sociais na Marcha das Vadias no Brasil. In:

Revista Ártemis, vol. XV, no 1, p. 33-43, jan/jun, 2013. Disponível em:

<http://bit.ly/30uZ3DV>. Acesso em: 6 jul. 2016.

HALL, Stuart. A identidade cultural na pós-modernidade. Rio de Janeiro: DP\&A, 2003.

JULIÃO, José Nicolao. O pragmatismo de Nietzsche e o seu desdobramento estético segundo Habermas. In: Revista Trans/Form/Ação, vol. 31, n. 1, 2008. Disponível em: <http://bit.ly/2Nse8mb>. Acesso em: 6 maio 2017.

LATOUR, B. Reagregando o social: uma introdução à teoria do ator-rede. Salvador: EDUFBA-Edusc, 2012. 34, 2013.

Jamais fomos modernos: ensaio de antropologia simétrica. São Paulo, Editora

LEMOS, A., PASTOR, L. Internet das coisas, automatismo e fotografia:

uma análise pela Teoria Ator-Rede. In: Revista Famecos, Porto Alegre, v. 21, n. 3, p. 1016-1040, setembro-dezembro 2014. pp. 1016 - 1040. Disponível em: <http://bit.ly/2ZeNPa8>. Acesso em: 24 abr. 2017.

MAFFESOLI, M. Saturação. São Paulo: Iluminuras/Itaú Cultural, 2010.

MAINBERGER, Sabine. No remoinho da tendência espiral - Questões de estética, literatura e ciências naturais na obra de Goethe. In: Estudos Avançados, vol. 24, n. 69, 2010. Disponível em: <http://bit.ly/33Wofp6>. Acesso em: 6 maio 2017.

MORE, T. Utopia. NY-EUA: Everyman’s Library, 1992.

SHANNON, C.; WEAVER, W. The mathematical theory of communication. Chicago-EUA: University of Illinois Press, 1949. 